\title{
EASE OF INDONESIAN SHIP MORTGAGE EXECUTION FOR A SHIP THAT LOCATED OUTSIDE THE JURISDICTION OF THE STATE TO SUPPORT INTERNATIONAL SHIPPING BUSINESS
}

\author{
Fani Martiawan Kumara Putra \\ Author \\ Faculty of Law \\ Wijaya Kusuma Surabaya University \\ Surabaya, Indonesia \\ fanimartiawan@gmail.com
}

\author{
Agus Yudha Hernoko \\ Co-Author \\ Faculty of Law \\ Airlangga University \\ Surabaya, Indonesia \\ yudha_fhunair@yahoo.co.id
}

\begin{abstract}
Globalization continues to have a major impact on the economic aspect. The field of marine transportation plays an important role and becomes one of the supports to the smoothness of economic development. The shipping business development brings the consequences of increasing interest in credit with a ship as the collateral object through Mortgage. Globalization demands the shipping business to be across borders, the impact is when the ship is being Mortgaged, the execution of the ship itself when the debt matures will be difficult to be done, due to inadequate legal rules and not all countries have ratified the ship's arrest convention. This study aims to provide a solution in order to achieve ease of execution of the Mortgaged ship that have crossed the state border that will support the shipping business development. This is a normative research. The results of this study, it is required the regulatory equality or at least the regulations that fit the times, that regulate the institution of collateral with ship objects in various countries. This will provide recognition, and guarantee the settlement (execution) of ship Mortgage from a country in another country, whether the country has or has not ratified the ship's arrest convention.
\end{abstract}

Keywords-Mortgage, Ship as Mortgage Object, Execution

\section{INTRODUCTION}

Marine transportation plays an important role in infrastructure development in Indonesia. Therefore, entrepreneurs in the field of marine continue to appear, resulting in a fairly tight competition among them. In order to maintain the existence of its business amidst the dense of business and competition, make shipping company to improve the quality of their business in various sectors, from facilities, to other sectors as supporting the business. Of course in the development of all these facilities require a lot of capital. The availability of capital or funds for the improvement of the quality of this voyage becomes very important for the business development of the shipping business. Credit application becomes one of the ways to fulfill the availability of this capital, either to financial institution of Bank or Non-Bank. Neither the Bank or Non-Bank provides loans, of course they must pay attention to the precautionary principle, especially when the creditor is Bank. The precautionary principle realized in accordance to Law No. 7 of 1992 concerning Banking (hereinafter referred to as the Banking Law), Article 29 of the Banking Law stipulates that the Bank in conducting its business must pay attention to the health of the Bank, one of which is by always applying the principle of prudence. The Bank's prudent principle in providing credit is reflected in Article 8 of the Banking Law which in the aforementioned explanation of the Article, is written down a few things known as $5 \mathrm{C}$ (now increased to $6 \mathrm{C}$ ). One of the most important of $6 \mathrm{C}$ it is Collateral.

Productive credit, can be used by individuals or legal entities engaged in marine transportation (the shipping company) to develop its business in the face of such competition is rife. Credit oriented such case, then its collateral aspects can be easily met with designated a ship, given the ship is the most dense objects of capital owned by individuals or legal entities engaged in the business sectors shipping. Therefore, when a ship is used as collateral that does not mean it is a manifestation of the last choice of the creditor in searching for the debtor's capitalintensive object. According to Law no. 17 Year 2008 on the voyage (hereinafter referred to as the Shipping Law), Article 60 paragraph (1) editorial asserts that when the ship will be used as collateral, it must first be registered, and the Mortgage is an institution that is used. Registration ship itself governed by Article 158 of the Shipping Law, which the ship must have the following criteria: (a). The weight of a gross tonnage of at least 7 GT (gross tonnage); (b). Owned by an Indonesian citizen or legal entity established under Indonesian law and domiciled in Indonesia; (c). Ship 
owned by Indonesian legal entity which is a joint venture majority owned by citizens of Indonesia.

Mortgage can be imposed on ships as the legislation governing mortgage today. The arrangement is spreaded, which basically ship Mortgage is currently regulated in the Burgerlijk Wetboek (hereinafter abbreviated as BW), the Wetboek van Koophandel (hereinafter abbreviated WvK), Herzeine Indonesisch Reglement (hereinafter abbreviated as HIR), Shipping Law, Government Regulation No. 51 of 2002 About Shipping (hereinafter referred to as PP Shipping), and the Regulation of the Minister of Transportation No. 39 of 2017 on Registration of Ships (hereinafter referred to Permenhub Registration of Ships).

In the above arrangements, legal protection is provided for the creditors and debtors. Particularly for creditors, the execution of a given institution when debtors have been rated in default. As per Article 224 HIR jo. Article 60 paragraph (4) of the Shipping Law jis. Article 31 paragraph (3) Permenhub Registration of Ships, given to the creditors in the form of execution rights are burdened ship mortgage was, by utilizing executorial title contained in the Deed Grosse of Ship Mortgage. In addition, through Article 1178 (2) BW Mortgage holders are granted the right to ship (creditors) to carry out the execution through Parate Executie institutions by including a clause Eigenmachtige Verkoop. Mortgage ship execution can only be done in both ways. While other guarantees, it has three execution agencies.

Execution of collateral objects ship Mortgage as a form of creditor's protection in credit settlement, encountered problems and cannot be implemented, when the object of the ship is outside the jurisdiction of Indonesia. This situation is caused because of the existence of a legal vacuum in Indonesia to lay the seizure of execution and execution on Indonesian ship that was outside the jurisdiction of Indonesia. The legal vacuum is because Indonesia has not ratified the Arrest of Ships Convention 1999. Meanwhile, not all States can ratify the Arrest of Ships 1999 Convention, because there is a clause in the Convention that could jeopardize the sovereignty of a State. This legal vacuum can certainly also affect the inhibition of international shipping business.

Based on the background above, the issues to be discussed in this paper is the object of collateral Mortgage execution solution for a ship that located outside the jurisdiction of Indonesia, to support the international shipping business.

\section{MethoD}

This research is a normative research, which means the findings and discussion done in this research are based on Indonesian law regulation, and the problematic are caused by the lack of Indonesian law regulation. This research is not based on social respond that came from a law regulation.

\section{FIndings AND DISCUSSION}

Ship mortgage is a security interest material. This is not explicitly mentioned in the legislation, but it is implicit in the characteristics of Mortgage itself which is a hallmark of material rights, while material rights can also be material security. One characteristic of the material rights attached to the Mortgage is Droit de Suite. Droit de suite is its inherent right over it, whenever and wherever it is located. Droit de suite in conjunction with the absolute principle (absolute) will open up the possibility of rights-holders to sue material (zaakelijk actie) on the property right. Droit de Suite for ship Mortgage is provided in Article 1163 paragraph (3) and 1198 BW. Droit de Suite rule has not been set in the present Mortgage (Shipping Law, Permenhub Registration of Ships and Sailing PP), so we still have to refer to the BW. Please note that up to now there are 41 (forty-one) Articles in BW regarding Mortgages, which can protect creditors and debtors, which have not been accommodated in current ship mortgage regulations.

In principle, collateral material can only be born in a manner agreed upon in advance, and then do the fulfillment of the principle of publicity. The material security agreement must be separate from its debt agreement. Similarly, in a process of guaranteeing an object, there are two agreements, namely the principal agreement (debts) and the asesoir agreement (guarantee agreement). Disclosed by Elizabeth Dalton as follows: "To be valid, a secured transaction must contain an express agreement between the debtor and the secured party. The agreement must be in writing, must be signed by both parties, must describe the collateral, and must contain language indicating a grant of a security interest to the creditor. The security associated with the principal agreement is said to attach. Attachment simply means that the security side of the agreement is complete and legally enforceable. To completely secure a secured transaction, or perfect the security, the secured party should file a financing statement with the local public records office, Secretary of State, or other appropriate government body. Failure to perfect the security may have drastic consequences for the secured party who does not possess the collateral, although such failure does not automatically mean that the security will be lost."[1] Elizabeth Dalton used the term "Principal Agreement" (which means principal agreement) to represent an agreement that debts can be attachment security agreement. It is therefore natural that his bail agreement referred to as the "Additional Contract" (which means assistance agreement or additional agreements).

The substance of the security agreement is not the obligation of the parties (in particular debtor) to fulfill his achievement (pay debts), because the liability is stipulated in the agreement debts (principal agreement). The substance of the guarantee agreement (accessoir agreement) involves only one party being liable, and therefore not an obligatory agreement, therefore this guarantee agreement does not result in a engagement. In contrast to the debt agreements as its parent, the contents of both parties are burdened with obligations, therefore obligatory agreements and, of course, engendering engagement. Although the warranty agreement 
does not give birth to the engagement, the debt agreement as the parent of the guarantee agreement still gives birth, so the binding power of the parties in the guarantee agreement (accessoir agreement) can be proven from the debt agreement.[2]

Although just an additional agreement, it gave birth to a stronger right than the right that was born by the principal agreement. The right of material security is truly a trustworthy bodyguard for personal rights arising from credit agreements as its commanding officer. As a bodyguard, it is this right of security guarantee that will appear first to overcome the impact of the debtor's default to obtain an early repayment, in order to save the receivables born from the credit agreement as commander.[3] On Mortgage insurance agency, identification of the guarantee agreement (asesoir agreement) governed by Article $1171 \mathrm{BW}$ stressed that the mortgage can only be given by an authentic deed. This authentic deed is mentioned in Article 60 of the Shipping Law, which is a Mortgage Deed made by the Registry Officer and Ship Registrar. The second editorial article shows further documents in addition to the agreement document debts, namely the existence of an additional agreement, which is intended as the validity of the mortgage.[4]

In a security agreement, objects belong to debtor's collateral is something that has a value, which is tied into agreements debts, in order to guarantee the creditors for the settlement of its accounts receivable. In the absence of a collateral item, then what will happen is merely a contract for a debt or a receivable and an obligation to comply. Guaranteeing an object means releasing some power in order to guarantee its debt. The essential element of the collateral object is not actually the categorization of the object, but most importantly it has economic value and is transferable. So that its elements in debts with guarantees are: (1). The existence of debt agreements; (2). The existence of the debtor; (3). The existence of creditors who become guaranteed parties: (4). There is a guarantee object; (5). The existence of an agreement whose contents give the guarantee rights on the object of guarantee, to the creditors. [5]

An agreement of debts which lies in material security therein, then execution can be one facility for creditors in the case of debt repayment when the debt is already billed while the debtor is defaulted. As Sri Soedewi asserts that natural credit relationship where there is an obligation of achievement of debtors and creditors rights to the achievement of, the legal relationship will be smoothly implemented if both parties meet their obligations. But in relation credit already billable (opeisbaar) if the debtor does not carry out the feat voluntarily, the creditor has the right to demand the fulfillment of its receivables (right execution) for the assets used as a guarantee debtors[6]

Ship mortgage in Indonesia can be recognized and protected by Indonesia when it was charged with unauthorized mortgage according to regulations in Indonesia, one thing is determining the terms of validity of ship mortgage is a mortgage that must be registered. Stressed in Article 1179 BW that bookkeeping everything must be done in a mortgage bond registers are provided for the public, and if it is not done then a mortgage will not have any power. This Ship Mortgage publicity further regulated in Article 60 paragraph (2) of the Shipping Law, which asserts that the registration of ship mortgages are executed by the Registry Officer and Ship Registrar (P3BK) at the place of registration of the ship. Arrangement of Article 60 of this Shipping Law stems from the mandate of Article $1171 \mathrm{BW}$ which affirms the deed of ship Mortgage shall be an authentic deed. The appointment of the party authorized to make an authentic deed of ship Mortgage, only implemented in 2002 through the PP Shipping. Article 33 Paragraph (1) The Shipping Regulation affirms that the Mortgage charge on the ship is made by the Mortgage Act by the Registry Officer and Ship Registrar (P3BK) at the ship register.[7]

In addition to obtaining recognition and protection in Indonesia, Indonesian ship Mortgages also need to be acknowledged by other countries. Recognition of another State, of course its instrument is an international agreement or Convention. Convention concerning the recognition of mortgages in other countries, is the International Convention on Maritime Liens and Mortgage 1993. The Convention contains about Mortgage, Mortgage and receivables that can be registered in any form and is charged on commercial ships is to be recognized and enforced in the States participants if it has been done in accordance with the laws and regulations of the country in which the ship is registered. Indonesia has ratified the International Convention on Maritime Liens and Mortgages in 1993 through Presidential Decree No. 44 of 2005 on the Ratification of the International Convention on Maritime Liens and Mortgages in 1993.

Recognition of Indonesian Ship Mortgage by another State, when the ship which has been mortgaged it sailed across national borders, can be carried out because the ratification instrument of the International Convention on Maritime Liens 1993 has implemented, but to law enforcement Mortgage ship (execution), on ships sailing across a border, it can be implemented through the instrument Arrest of Ships Convention, 1999. However, for the latter cannot be implemented in Indonesia, because Indonesia has not ratified the Arrest of Ships Convention 1999. That means the International Convention on Maritime Liens and Mortgage 1993 and Arrest of Ships Convention 1999 is the two Conventions are interrelated. 
Based on the theory of international law, namely floating country, it may be warranted when there is an understanding that the ship can be executed by the State whose flag is flown by the ship, because the ship including jurisdiction. However, in accordance with the law that developed in the business world, including also contained in the law in Indonesia (Articles 577 and $578 \mathrm{Rv}$ ), the execution of the ship there must be a limit, among others, there is freedom for the debtors to master the ship, while the ship is considered ready to sail to fulfill its engagement with a third party. Essentially, when a cruise ship activity (either the loading and unloading of goods, or sailing) and yet lean, the ship cannot be done a foreclosure execution.

When a State determined to seize the ship that is being mortgaged and the ship was outside their jurisdiction, while the ship was completed activity voyage, the ship has the potential to immediately resume his voyage, when ready to sail, the ship cannot be seized and execution as well as the above mentioned settings, such things will happen continuously vice versa. Therefore, in order to execute for the execution, there is a need for assistance from the State in which the ship is leaning, for the party of that State immediately seizes confiscation on the ship concerned. Notice of the confiscation of the ship was delivered before the ship completed loading and unloading, and confiscated during loading and unloading of the ship from the ship was completed, so the ship did not immediately prepare for the next voyage route.

Confiscation, detention of the ship, which required a partnership between the States, as above, can be realized with the provisions of the instrument Arrest of Ships Convention, 1999. Setting of the Convention, at its core is about the detention of the ship where there is a maritime lien. This means that when not as maritime liens, the Convention cannot be used in the seizure of a ship.

Keep in mind and noted, that the real Arrest Convention of Ships 1999 is a bridge, to facilitate the State and the State one another in terms of the fulfillment of civil rights of the people, by holding a ship which will culminate in the execution of the ship. This Convention shall apply only to States which have ratified this Convention. For example, Indonesia would like to ask other countries to withhold aid Indonesian ship that was leaning in that State, when that State has ratified the Convention, while Indonesia has not ratified this Convention, then the request cannot be executed.

Upon further investigation, it was found that the Arrest of Ships Convention 1999 is a form of legal developments, so that the state which has not ratified this Convention and harmonize in a legislation, meaning that the State does not have the appropriate legal rules date. Maritime duties in Indonesia arranged in the realm of ship Mortgage, meaning that Indonesia is considered not to have the rules of the ship's ship in accordance with the development of the era. It is thus understandable that the most important is the urgency of a rule of law (in this case the law of ship Mortgage guarantees) in accordance with the needs of the development of the era.

Laws that are in accordance with the needs of the development of the times, will become laws that can in fact be respected and recognized by other States. This can be evidenced through the cases that happened in Indonesia in 1976. The case between Bank of America Leasing and Capital (Hong Kong) Ltd. VS PT. Phoenix Liao Chi Ming (Authorized Representative of Reliance Navigation Co. Ltd. SA And Tsao Wen Lung (MV "AN SHIN" ex "TA YA" captain) .The ship with a Panama-flagged 4680 GT (gross tonnage) and started flying the Panama flag in 1973 with the name "TA YA", and renamed to be "AN SHIN" in 1975 while still a Panamanian-flagged. The ships are mortgaged to the Bank of America Leasing (Hong Kong), Bank of America Leasing (Hong Kong) turned the boat was used as collateral to one of the National Indonesia (PT. Phoenix). The ship was carrying minerals from Africa to Tokyo, and ordered the Indonesian side to stop at Tanjung Priok. The ship was then arrested, and the creditor (National Company) filed a case before the District Court East Jakarta, the seized ship was seized by the East Jakarta District Court and then declared his right to the National Company (PT. Phoenix) as a creditor who has a bill for lending money to the ship owner. Bank of America Leasing (HK) denies the East Jakarta District Court that in essence requires that the transfer of ownership of the ship be canceled, because the ship is still attached to Bank of America Leasing (Hong Kong) Mortgage which has been validly registered in Panama. Through the assistance of the Panama consulate in Indonesia it is also conveyed that in accordance with the applicable law in Panama, when the ship is still burdened with Mortgage, the ship will not be able to reverse the name and write off the ship as well as write off the mortgage prior to the debt repayment to the creditor (Bank of America Leasing (Hong Kong))..

The end of this case is the lack of peace between Bank of America Leasing (Hong Kong) and the Indonesian National enterprise yes to these two plays as a creditor. Peace in the form of allowance by Bank of America Leasing (Hong Kong) to the Indonesian National Company (PT Phoenix) that has obtained the ship, to replace the position of the debtor, and begin paying the installment at Bank of America Leasing (Hong Kong), using Mortgage guarantee over the ship is the same, until it has been paid off then the ship can be done behind the name on behalf of the Indonesian National Company (PT Phoenix) with the help of the port. The ship was renamed PHOENIX 1 in 1978 under the Indonesian flag and sank on 14 July 1978 near Biaro Island, Sangihe Island, Indonesia.[8]

Through the above cases, it can be proven that the actual mortgage on the ship was protected by the International, although the Bank of America Leasing (Hong Kong) raised no objections, the ship will not be granted to be renamed and crossed the ship registration, also crossed out the registration mortgage was by the port (harbor master) in Indonesia or elsewhere, because the registration of the ship will not be dropped when the flag of another State is still attached and / or special markers that the ship is also being used as collateral by the other party was still attached. Similarly to the write-off ship registration or registration of ship mortgages (which are known from the existence of a special marker on the ship), already 
certain to be done with the permission and coordination of the flag State.

In the case above, in 1976, the ship's Mortgage rules in Indonesia were still based on WVK and BW, both rules were still very able to follow the development of the era, in that era Mortgage ships in the Netherlands are also still based on the same BW and WVK. Indeed at that time there was already Arrest of Seagoing Ships Convention (Brussels, May 10th, 1952), but not so be urgency for the convention ratified widely, because the shipping business is not so developed rapidly, and the practice of guaranteeing the activity of shipping is still rare, which means the emergence of receivables maritime which then becomes a problem that is also still rare.

Thus the most important point, there are regulations on ship mortgage that is tailored to the needs of the development, which also includes customized with provisions also apply in the international world, among other Conventions have been held regarding the issue along with the ship mortgage creditors' rights, and guarantees allows with the ship and its cargo, so Mortgages ships in Indonesia is also recognized in other countries and Mortgages in other countries also recognized in Indonesia. This thinking leads to the urgency of legal reform of the ship's Mortgage guarantee agency.

In addition to being recognized and protected internationally, then of course the next advantage is about the execution. Through such cases it is evident that Indonesia can legally hold the ship, and the detention of such ships has legal certainty, as well as other interested States not objecting to the norm of detention, but the objection is made only to the name of the perpetrator, valid by another State. Whereas in the Indonesia did not ratify, accede to and even not harmonize the rules of Convention Arrest of Seagoing Ships (Brussels, May 10th, 1952), are added to a legislation in Indonesia.

Based on the previous elaboration, that there is an urgency to ratify the Arrest of Ships Convention, 1999, because of problems related to the containment ship maritime liens. However not all States to ratify the Convention on the Arrest of Ships 1999, because there is a clause in the Convention that could jeopardize the sovereignty of a State, given the country floating theory as has been discussed previously. Including Indonesia cannot ratify this convention. Nevertheless, the need to find a way out, in order to meet the demands of its ship mortgage rules that fit the needs of the changing times in both the national and international realm.

In the Arrest of Ships Convention 1999 there are several important Articles, among others:[9]

Article 2 - Powers of Arrest

A ship may be arrested or released from arrest only under the authority of a Court of the State Party in which the arrest is effected;

A ship may only be arrested in respect of a maritime claim but in respect of no other Claim;

A ship may be arrested for the purpose of obtaining security notwithstanding that by virtue of a jurisdiction clause or arbitration clause in any relevant contract, or otherwise, the maritime claim in respect of which the arrest is effected is to be adjudicated in a State other than the State where the arrest is effected, or is to be arbitrated, or is to be adjudicated subject to the law of another State.

Subject to the provisions of this Convention, the procedure relating to the arrest of a ship or its release shall be governed by the law of the State in which the arrest was effected or applied for.

\section{Article 3 - Exercise of Right of Arrest}

Arrest is permissible of any ship in respect of which a maritime claim is asserted if:

c. The claim is based upon a mortgage or a "hypothèque" or a charge of the same nature on the ship; or

f. The claim is against the owner, demise charterer, manager or operator of the ship and is secured by a maritime lien which is granted or arises under the law of the State where the arrest is applied for.

Article 4 - Release from Arrest

A ship which has been arrested shall be released when sufficient security has been provided in a satisfactory form.

\section{Article 5 - Right of Rearrests and Multiple Arrest}

Where in any State a ship has already been arrested and released or security in respect of that ship has already been provided to secure a maritime claim, that ship shall not thereafter be rearrested or arrested in respect of the same maritime claim unless:

a. The nature or amount of the security in respect of that ship already provided in respect of the same claim is inadequate, on condition that the aggregate amount of security may not exceed the value of the ship; or

b. The person who has already provided the security is not, or is unlikely to be, able to fulfil some or all of that person's obligations;

c. The ships arrested or the security previously provided was released either:

ii. Because the claimant could not by taking reasonable steps prevent the release.

The above provision has been duly incorporated into the refurbished ship mortgage rules, because his purpose and the principal setting Arrest of Ships Convention 1999 lies in the above provisions. Conditions other than those mentioned above, are other provisions that are common to a convention, and also provisions that can be assessed harming the sovereignty of a State.

This means that by inserting the provision, ship mortgage rules in Indonesia would be in accordance with the needs of the changing times in the international sphere, especially welcome after their urgency to ratify the 1999 Arrest of Ships Convention by States that its transportation business develops. However other problems arise, when the ship mortgage arrangement completely refurbished with the clauses above, will then other countries so willing to help the containment ship, when fixed Arrest of Ships Convention 1999 was not ratified.

Needs to be understood that not all States to ratify Arrest of Ships Convention 1999, but almost all countries feel the urgency to ratify the 1999 Arrest of Ships Convention because 
of its benefits. Based on examples of the cases that have been outlined above, States are now rightly understand and restore the practice of the containment ship with a benchmark that other State Mortgage rules at least equivalent to the rules mortgages in the Country. Similarly, when it is applied not only for Indonesia but also for other countries, then at least be able to facilitate the execution of the object that is being mortgaged ship, but was outside the jurisdiction of the State flag and the state flag needs help to hold the ship in question..

One thing that cannot be ruled out, so as to realize the purpose of this discussion, is the role of the various parties involved in ensuring the ship, plus the relevant parties in the international relations of a State, such as the registration of ships, the registration of mortgages ship, the Director General of Sea Transportation, the Court, as well as the Embassy. Roles and good cooperation among the parties serve targeted by the same parties in other countries, will be the determinant of the containment ship can be done by another State at the request of a State which has not ratified the Arrest of Ships Convention 1999, but has a ship mortgage rules in accordance with the needs of the development, also in his ship mortgage rules contain clauses core and existing critical in that Convention.[10]

\section{Conclusion ANd Suggestion}

Execution ship which is being secured by using a mortgage, while the ship is outside the jurisdiction of the flag state, will meet obstacles when there is no assistance from the State where the ship rests. Currently the aid in the form of the containment ship that is submitted to the State in which the lean ship cannot be performed when the two countries did not ratify the Arrest of Ships Convention 1999. The convention, while not necessarily be ratified by all the countries. This hinders shipping business activities. One way out is to change the rules of Mortgage ship according to the developmental needs of the era both in the realm of national or international. One of them is to take the core provisions of the Convention Arrest of Ships 1999 are (there are some Sections) was later included in the legislation in Indonesia on Mortgage ship. The case occurred in 1976, can be an example and a lesson, that in practice, though not ratified Arrest of Ships Convention, 1999, provided that the rules of mortgage ships of the two countries are equivalent, then the seizure of the ship can be done, of course, with the communication and cooperation of the parties related such as the registration of the ship, the ship mortgage registration, the Director General of Sea Transportation, the Court, as well as the Embassy.

Advice for Indonesia, is expected to lawmakers promptly update the rules Mortgage ship, with the necessary substance, to also pay attention to research and scientific writing, and the findings that have been done with the ship Mortgage discussion.

\section{REFERENCES}

[1] Elizabeth Dalton, The Consequences of Commercially Unreasonable Dispositions of Collateral: Haggis Management, Inc. VS Turtle Management, Inc., The Utah Law Review Journal Year 1986, University of Utah, Salt Lake City, United States, 1986.

[2] Fani Martiawan, Pembaharuan Hukum Lembaga Jaminan Hipotek Kapal, Disertasi, Universitas Airlangga Surabaya, 2017.

[3] Moch. Isnaeni, Pengantar Hukum Jaminan Kebendaan, Revka Petra Media, Surabaya, 2016.

[4] Fani Martiawan, Op.cit., h. 88

[5] Ibid, h. 83 .

[6] Sri Soedewi, Hukum Jaminan di Indonesia, Pokok-Pokok Hukum Jaminan dan Perorangan, Liberty, Yogyakarta, 2007.

[7] Fani Martiawan, Op.cit., h. 150.

[8] Sudargo Gautama, Indonesia dan Konvensi-Konvensi Hukum Perdata Internasional, Alumni, Bandung, 1993.

[9] Arrest of Ships Convention 1999.

[10] Fani Martiawan, Op. cit., h. 262. 
